\title{
Algumas notas sobre o panorama da blogosfera portuguesa*
}

António Granado**

2003 é, sem dúvida o ano dos weblogues em Portugal. Apesar de o fenómeno ter começado no nosso país no início de 1999 - com weblogues como o Macacos Sem Galho, o Gildot.org, o Dee's Life, o Velouria.org -, a verdade é que 2003 viu aumentar exponencialmente o número de blogues escritos por portugueses e trouxe até à ribalta este fenómeno até aqui muito localizado.

O blogues em .pt, que começou a indexar os weblogues portugueses em 2003, começou por ter 174 blogues em 25 de Janeiro. Em 25 de Março eram já 280. Em 7 de Maio, 400. Em 6 de Junho, 605. Em 2 de Julho, 905. O blogues em .pt acabou nesse mesmo dia, porque a indexação se tornou "ingerível para quem tem outros afazeres”, escreveu o Pedro Fonseca, autor da página.

Neste momento existem outros sites que indexam weblogues portugueses. O Bloco--Notas atingiu na semana passada [meados de Setembro de 2003] mais de dois mil weblogues portugueses indexados, ainda que muitos deles, criados na euforia que se viveu na Primavera e no início do Verão deste ano [2003], já tenham fechado as suas portas, ou não sejam actualizados regularmente. Numa leitura apressada das actualizações do Bloco-Notas, calculo que o número de weblogues portugueses que são actualizados diariamente ronde os 500 .

A este súbito interesse dos media pela blogosfera, e consequentemente dos seus leitores, não é alheio o facto de, nos últimos meses, algumas personagens mediáticas portuguesas terem criado o seu próprio weblogue. Depois dos blogues de política, à esquerda e à direita - dos quais os mais famosos são A Coluna Infame (entretanto desaparecida) e o Blog-de-Esquerda, foi o aparecimento do Abrupto - http:// abrupto.blogspot.com - de José Pacheco Pereira que fez explodir este fenómeno até então circunscrito a umas centenas de aderentes em Portugal. Em 20 de Março, Pacheco

\footnotetext{
* Conferência de abertura, proferida no 1. ${ }^{\circ}$ Encontro Nacional sobre Weblogues, realizado na Universidade do Minho, em 18 e 19 de Setembro de 2003.

** Jornalista do Público, especializado em jornalismo sobre ciência, área do seu mestrado na Universidade de Boston. É docente de Jornalismo na Universidade de Coimbra e prepara doutoramento na Universidade de Leeds sobre "The construction of science news in the European Union: the journalists' constraints and the influence of Internet in their newsgathering routines". Mantém um dos mais antigos weblogues portugueses, especializado em media, o Ponto Media (http://ciberjornalismo.com/pontomedia.htm).
} 
escreve no Público um texto sobre weblogues que, indubitavelmente, faz crescer o número de visitas aos weblogues existentes em Portugal. A 6 de Maio, lança o seu próprio weblogue e, quer queiramos quer não, a blogosfera portuguesa nunca mais foi a mesma.

Ao weblogue de Pacheco Pereira seguiram-se os weblogues de muitos jornalistas que, na Net, encontraram uma forma de extensão do seu trabalho diário, ou um lugar para exprimir as opiniões que tantas vezes reprimem nos seus textos jornalísticos. $\mathrm{O}$ aparecimento de personagens mediáticas na blogosfera criou na comuni-dade que iniciou este fenómeno em Portugal alguma desconfiança e receio que jornalistas e políticos pudessem invadir e monopolizar um espaço até agora considerado livre. $\mathrm{O}$ aparecimento de artigos jornalísticos onde quase sempre eram referidos os mesmos weblogues, escritos pelas mesmas personagens mediáticas, ajudou a cavar ainda mais esse fosso. Os “pioneiros” estavam a ser esquecidos em favor dos "pavões”.

Por parte de alguma comunicação social, o fenómeno dos weblogues não foi também bem recebido, porque foi entendido como uma ameaça ao quarto poder estabelecido. Expoente máximo dessa rejeição foi o artigo de Pedro Rolo Duarte, editor de um dos mais influentes suplementos da imprensa diária portuguesa - o DNA, que advogava mesmo a proibição de acesso aos weblogues a todos aqueles que já tinham espaços na imprensa tradicional: “Acho que uma das maiores virtudes da imprensa é o facto de ser finita no espaço e no tempo. Isto obriga a quem escreve, quem edita, quem publica, a escolher - e é na escolha, é nesse acto individual, perigosamente ditatorial, da escolha, da opção, que está a 'flor do sal' desta profissão, desta paixão. Nesta medida, quando os profissionais do jornalismo se envolvem em 'blogues', estão a negar a essência do seu trabalho e a viciar o jogo da liberdade. Se houvesse leis sobre a matéria e eu pudesse legislar, os 'blogues’ existiam. Mas tinham esta reserva legal: só a eles deveriam ter acesso os que, pelas mais diversas razões, não têm espaço próprio nos meios de comunicação. Ponto final”.

A blogosfera portuguesa, termo que alguns puristas continuam a recusar, tem algumas características que vale a pena analisar e discutir aqui, nesta que é a primeira intervenção neste Encontro de Weblogues e que, por isso, se quer que lance pistas de discussão para os temas de amanhã [19-09-2003].

Das minhas leituras dos weblogues portugueses, destaco aqui três características que me parecem importantes e que gostaria de ver discutidas:

- Muitos weblogues opinativos/analíticos, poucos informativos.

A grande maioria dos weblogues portugueses está na área da análise e da opinião. Quase todos querem discutir qualquer coisa, poucos dão informações que nos ajudem a contextualizar essa coisa. Alguns dos mais famosos weblogues portugueses vivem mesmo obcecados com a divisão esquerda/direita, como se isso fosse realmente importante ou todos nós pensássemos nisso antes de escrever o que escrevemos todos os dias. Uma boa polémica é melhor do que uma boa informação, pensam muitos dos que têm weblogues em Portugal. 
- A grande maioria funciona em circuito fechado.

São raros os links para a Internet, para textos exteriores à blogosfera (muitos mesmo não têm quaisquer links que não seja para outros weblogues) e o circuito de discussão dos temas é fechado. Abra-se um weblogue português ao acaso e veremos que eles discutem os posts uns dos outros, entram em polémica por tudo e por nada, raramente trazem informação nova para a discussão.

- Não há jornalismo nos weblogues nacionais.

Como consequência desta tendência opinativa, não há casos de jornalismo na blogosfera nacional. Mesmo os jornalistas que têm weblogues limitam-se a apontar outras leituras ou a fazer opinião, dando raramente notícias nos seus weblogues. $\mathrm{O}$ facto de os media, onde esses jornalistas trabalham, não terem ainda weblogues institucionais faz com que qualquer divulgação de informação noticiosa em primeira-mão possa soar a traição para com o jornal que os alimenta e os veste. Os que têm medo dos weblogues como concorrentes do jornalismo tradicional ainda vão ter de esperar porque os "outsiders" também ainda não conseguiram mostrar que é possível fazer jornalismo nos blogues.

Tentando fazer um pouco de futurologia, acho que, nos próximos meses, vamos assistir em Portugal ao aumento de alguns fenómenos que já se fazem sentir noutros países e que ainda aqui não chegaram em força.

- O crescimento de weblogues do tipo "Muito Mentiroso", escritos por anónimos que, por isso, não têm qualquer necessidade de proteger a sua credibilidade, juntando realidade a ficção. Nos primeiros tempos, podemos achar que as informações que estes sites prestam são boas, mas, quando temos conhecimento de alguma em primeira mão, logo vemos que, muitas delas, não devem passar de efabulações sem qualquer verdade.

- O nascimento de moblogs em quantidades industriais, alimentados a partir de telemóveis com câmara fotográfica. Alguns simples diários, outros roteiros de viagens, outros invasão clara da privacidade. Se alguém tem alguma dúvida que isto pode acontecer, basta visitar mobileasses.com, um site que se limita a publicar fotos de rabos de mulheres de calças e que já tem várias fotografias feitas em Portugal, sem conhecimento das fotografadas.

- A utilização de weblogues no ensino, uma área em que o curso do Minho e do Porto foram pioneiros em Portugal e que vai crescer ainda muito mais. Quando os professores universitários, e não só, perceberem as potencialidades desta ferramenta de publicação, vamos assistir a uma explosão do fenómeno.

Finalmente, acho que devemos pôr alguma água na fervura, quando discutimos os weblogues, para não pensarmos que isto é a melhor coisa desde a invenção da roda. No livro que publicou em 1995, chamado Diffusion of Innovations, o investigador Everett M. Rogers descreve a difusão das inovações que é, nas suas palavras, "o processo pelo qual uma inovação é comunicada através de certos canais ao longo 
do tempo" (Rogers, 1995: p. 11). De acordo com Rogers, o processo de inovaçãodecisão tem cinco níveis principais: conhecimento, persuasão, decisão, implementação e confirmação.

Rogers classificou ainda os que adoptam inovações em cinco categorias diferentes (Rogers, 1995: p. 262): os inovadores, os primeiros 2,5 por cento que aderem à inovação; os early adopters, os 13,5 por cento seguintes; a early majority, os 34 por cento que se seguem; a late majority, os seguintes 34 por cento; e os laggards ("os atrasados”), os 16 por cento restantes.

Apesar desta explosão dos weblogues em todo o mundo, que representa a possibilidade de qualquer cidadão se tornar editor de um espaço próprio com difusão global, é bom não nos esquecermos que, em termos desta escala criada por Rogers, estaremos em Portugal na fase dos “inovadores”, tendo alguns países/comunidades já passado à fase early adopters. A Internet é ainda um espaço a que só têm acesso os info-ricos e que, mesmo em todos esses países mais desenvolvidos, ainda não é acessível a todas as camadas da população. 